\title{
Characteristics of Liquid Product of Alkaline Treated Sargassum polycystum C.A. Agardh. from Lange Beach, Aceh
}

\author{
Anjar Purba Asmara ${ }^{1 *}$, Endaruji Sedyadi², Ilma Fistannisa Zette ${ }^{3}$ \\ ${ }^{1}$ Department of Chemistry, Faculty of Science and Technology, Universitas Islam Negeri Ar-Raniry Banda Aceh \\ Jl. Syeikh Abdur Rauf, Kopelma Darussalam, Banda Aceh 2311 Indonesia \\ ${ }^{2}$ Department of Chemistry, Faculty of Science and Technology, \\ Universitas Islam Negeri Sunan Kalijaga Yogyakarta \\ Jl. Marsda Adisucipto Yogyakarta 55281 Indonesia \\ ${ }^{3}$ School of Life Sciences, Faculty of Science, University of Technology Sydney \\ 15 Broadway, Ultimo, New South Wales 2007, Australia \\ Email: anjarpa@ar-raniry.ac.id
}

\begin{abstract}
Sargassum is known to have potential ingredients, such as essential nutrients and minerals, which are important for agroindustry and the environment. This study aims to determine the proximate properties of Sargassum polycystum C.A. Agardh from Lange beach and the optimum extraction period arising the liquid product. The dried seaweed was extracted using $0.1 \% \mathrm{KOH}$ at a constant temperature of $80^{\circ} \mathrm{C}$ for $120-600$ mins. Furthermore, nutrients content, $\mathrm{pH}$, electrical conductivity (EC) and total dissolved solids (TDS) of the afforded filtrate were quantified. As a result, the moisture, ash, fibre, carbohydrate, protein, and fat content were 7.16, 13.057, 20.33, 51.77, 6.12, and 1.57\%, respectively. The value of $\mathrm{pH}, \mathrm{EC}$, and TDS ranged around 4.69-7.27, 0.013-0.078 dS.m1, and 6.24-39.75 mg. $\mathrm{L}^{-1}$, respectively. The level of $N, P, K$, and organic C, were estimated around 0.30-0.81, $0.16-0.28,0.15-0.20$, and 0.32-0.80\%, respectively. Meanwhile, the content of Na, Mg, Ca, Fe, Mn, and Zn were observed from 112.04-212.61, 24.60-33.57, 146.59-280.92, 416.22-630.69, 18.25-27.73, and 19.8626.53 ppm, respectively. In conclusion, extraction for 120 mins seems to be preferable, as the observed parameters were above the minimum range.
\end{abstract}

Keywords: proximate, brown seaweed, liquid fertilizer, micro- and macronutrients

\section{Introduction}

In 2018, Food and Agriculture Organisation (FAO) of the United Nations (2018b) acknowledged Indonesia as the second major worldwide supplier of seaweeds contributing as $38 \%$ in the global trading development (FAO, 2018a). The national production increased dramatically from less than 4 million to 10.456 million tonnes in 2010 to 2017 , respectively, which was valued as IDR 21 trillion (Pusdatin, 2018). The farming activity produced such enormous values has attempted only at a half-scale of all potential resources, approximately 384.7 thousand Ha used from 769.5 thousand $\mathrm{Ha}$ (KKP, 2013). Therefore, an opportunity to maximise the economic commodity could be taken into account.

One of the unutilised farm space allowing a brown seaweed, Sargassum, is Lange beach situated in Lam Lhom, a rural area in Aceh Besar. It has been reported that raw material for manufacturing brown algae-based hydrocolloid, alginate, is in globally high demand, as much as 560 thousand tonnes per year, and worth US\$ 40 million (Nayar and Bott, 2014). Both the local and national communities could benefit from this resource by developing a practical framework to cultivate the marine plant and innovate profitable management systems of the by-products. Due to no scientific study of the species from the aforementioned location, a preliminary work including proximate profile seems to be crucial to underpin further action needed to decide the sustainable economic implementation.

Although domestic alginate manufacturer has been established since 1993, the volume of production has less contribution to the national income compared to the other phycocolloid industries, carrageenan and agar. Moreover, while the national order of alginate tends to increase every year, the commercial rate of the product is relatively more expensive than the two marine saccharides. In 2015, it was 3 times higher than agar-agar, and 4 to 6 times higher than carrageenan (Salim and Ernawati, 2015). In addition, some challenging factors such as lack of infrastructure to access the habitat of Sargassum, unadvanced cultivation technology apply, and less innovation in byproducts management system are likely to be considered as the main causes of the circumstance 
(Salim and Ernawati, 2015; Muslimin and Sari, 2017).

Darmawan et al. (2006) described two opposite effects of the application of alkaline treated sargassum (ATS) using $\mathrm{KOH} 0.1 \%$ as the primary solvent in the alginate production as following as either improving the quality of sodium alginate or generating liquid disposal. However, its waste can be applied in a further process converting it to sargassum liquid fertilizer (SLF) (Spurr, 2014 and Basmal et al., 2015). Scientifically, Sargassum thallus has been reported as the source of macroand micronutrients, humic acid, tannin, iodine, growth regulators (auxins, gibberellin, cytokininkinetin, cytokinin-zeatin), phenol and vitamin (Basmal et al., 2017). Furthermore, the absence of lignin layer in the plant affects to let the decomposition of essential substances for both crops and soil run smoother (Spurr, 2014).

Some studies have revealed enormous potential advantages of Sargassum ingredient to agroindustry and the environment. High level of essential nutrients and minerals has been associated to the effects of S. polycystum (Bharath et al., 2018) and S. vulgare extract (EI-Din, 2015) promoting the growth and productivity of leguminous plants; the improvement of photosynthesis pigments, protein, sugar, and ascorbic acid production as well as inhibition of nitrate reductase enzyme demonstrated by S. illisifolium extract (Pise and Sabale, 2010a) and S. wightii extract (Vijayanand et al., 2014; Divya et al., 2015; Divya and Reddi, 2017), stimulation of seed germination provided by S. pallidum (Turner) C. Agardh (Anisimov and Chaikina, 2014), S. vulgare (Salma et al., 2014) and S. myricocystum (Sujatha et al., 2015). Salinity, another important component, commonly expressed in $\mathrm{pH}, \mathrm{EC}$, or TDS, has also been closely related to the positive properties of the macroalgae extract. For instance, aqueous extracts of $S$. wightii and $S$. johnstonii with $\mathrm{pH}$ and $\mathrm{EC}$ as $7 \& 7.5$ and $6.40 \& 6.20 \mathrm{dS} / \mathrm{m}$, respectively, showed beneficial impacts on both chlorophyll and primary metabolites production and soil nutrition and moisture maintenance (Takoliya et al., 2019 and Patel et al., 2019). In addition, advantageous effects toward plants such as increasing the rate of growth and development and improving the volume and the mass of crops were exhibited by two species with different degree of electric conductivity: S. crassifolium (Sutharsan et al., 2014) and S. muticum (Silva et al., 2019) with pH and $E C$ value as 9 and $6.6-7.22$, and 4 and 0.1-0.2 dS. $\mathrm{m}^{-1}$, respectively.

With regards to ATS by-products study, Basmal et al. (2010) reported that heating Sargassum sp. at $80^{\circ} \mathrm{C}$ for 360 mins afforded the highest level of micronutrients and salinity parameters compared to three other shorter heating periods: 0, 120, and 240 mins. However, the research did not show the optimum extraction time that allows any observers to record the peak period characterised by a pointed top level of the achieved components. Therefore, along with proximate study, this work was conducted by adding two longer extraction time, 460 and 600 mins, to measure the essential components needed to classify the quality of the liquid product of Lange brown algae.

\section{Materials and Methods}

\section{Preparation and proximate analysis}

S. polycystum was taken from Lange beach in Lam Lhom (Aceh Besar) at $5^{\circ} 31^{\prime} 02.6 " \mathrm{~N}$ and $95^{\circ} 12^{\prime} 04.5^{\prime \prime} \mathrm{E}$. The fresh seaweed was rinsed with flowing water three times to separate undesired particles from the thallus. Afterwards, the sample was sun-dried for three days, followed by oven-dried at $60^{\circ} \mathrm{C}$ overnight. The dried Sargassum was powdered using a blender and then subjected to proximate analysis. The measurement of moisture, ash, fibre, carbohydrate, protein, and lipid content was carried out following AOAC methods (2015). All data were expressed in \% (w/w).

\section{Extraction}

The alkaline-based method described by Basmal et al. (2017) was adapted with a slight modification by putting a longer different time of extraction in place. The study employed six types of samples, including one control and five heat-treated samples. All samples were prepared by adding fine powdered Sargassum into $\mathrm{KOH} 0.1 \%$ with a ratio of $1: 10$ (w:v). Filtrate 1 as the control was obtained by filtering the mixture which was soaked for 60 mins at the room temperature. Meanwhile, five other samples - namely, filtrate 2, 4, 6, 8, and 10 - were the liquid product of the filtration of the mixture heated at $80^{\circ} \mathrm{C}$ for $120,240,360,480$, and 600 mins, respectively. Analysis of salinity properties and nutrients content were applied to all samples.

\section{Measurement of $\mathrm{pH}, \mathrm{EC}$, and TDS}

The $\mathrm{pH}$ value was determined using a digital $\mathrm{pH}$ meter while the EC value was estimated with an electrometer. The TDS measurement was observed through the gravimetric method.

\section{Analysis of nutrient content}

The total nitrogen content was measured using the procedure SNI 4146:2013. The sample was digested with boiling concentrated $\mathrm{H}_{2} \mathrm{SO}_{4}$ to obtain a 
green product. The mixture was then distilled to separate a liquid placed into a conical flask added with $\mathrm{H}_{3} \mathrm{BO}_{3} 4 \%$ and indicator $\mathrm{MR}$ and BCG. The distillate was subjected to a titration using $\mathrm{HCl} 0.1 \mathrm{~N}$ to reach endpoint (green-yellow). The level of $\mathrm{N}$ was calculated using the acid volume needed to neutralise the sample.

The analysis of organic $\mathrm{C}$ content employed the protocol of BPT (2005). The filtrate was added into concentrated $\mathrm{H}_{2} \mathrm{SO}_{4}$ and $\mathrm{K}_{2} \mathrm{Cr}_{2} \mathrm{O}_{7} 1 \mathrm{~N}$ and then stored for 30 mins. Into the mixture, concentrated $\mathrm{H}_{3} \mathrm{PO}_{4}$ was added and homogenised. The two dropwise of indicator DPA was added into the solution and titrated with $\mathrm{FeSO}_{4}$ to reach the endpoint (gree-blue). The concentration of $\mathrm{C}$ was estimated using the solution volume needed to neutralise the sample.

The concentration of $\mathrm{P}$ and $\mathrm{K}$ was calculated using the protocol of BPT (2005). Standard solution of $\mathrm{P}_{2} \mathrm{O}_{5}$ was prepared in $0,2.5,5,7.5,10,12.5$, and $15 \mathrm{ppm}$ while the standard solution of $\mathrm{K}_{2} \mathrm{O}$ was made in $0.5,10,15$, and $20 \mathrm{ppm}$ and then observed in spectrophotometer UV-vis at $650 \mathrm{~nm}$ wavelength. Into the sample, concentrated $\mathrm{HNO}_{3}$ and $\mathrm{HClO}_{4}$ was added and heated. After filtration, the resulted filtrate was diluted with aquades, added by $\mathrm{HNO}_{3} 2 \mathrm{~N}$, and ammonium heptamolibdat vanadate solution and homogenised. The mixture was observed under spectrophotometer UV-vis at $650 \mathrm{~nm}$ wavelength and then compared with the absorbance data of $\mathrm{P}$ and $\mathrm{K}$ standard to estimate the concentration.

The level of $\mathrm{Na}, \mathrm{Mg}, \mathrm{Ca}, \mathrm{Fe}, \mathrm{Mn}$, and $\mathrm{Zn}$, were determined using the procedure of AOAC (2015). Each standard solution of the minerals was prepared in $0,0.1,0.5,1,2,3$, and $4 \mathrm{ppm}$. The standard curve was made through atomic absorption spectroscopy (AAS) at wavelength number of $589.6 \mathrm{~nm}(\mathrm{Na}), 285.2$ $\mathrm{nm}(\mathrm{Mg}), 422.7 \mathrm{~nm}(\mathrm{Ca}), 248.3 \mathrm{~nm}(\mathrm{Fe})$, and 279.5 $\mathrm{nm}\left(\mathrm{Mn}\right.$ and $\mathrm{Zn}$ ). Into the filtrate, concentrated $\mathrm{HNO}_{3}$ was added and then heated exhaustedly. The sample was diluted with aquades up to $100 \mathrm{~mL}$. The absorbance of the sample was measured at the proper standard wavelength depending on the type of the mineral while the concentration was calculated by comparison between the absorbance of the sample and the proper standard curve.

\section{Results and Discussion}

\section{Proximate profile}

In the solvent-based extraction, the permeability of molecules of the solvent affecting to the penetration into cell wall appears to be mainly driven by the water content of the sample since $\mathrm{H}_{2} \mathrm{O}$ molecules could compete to the solvent. The higher permeability of the solvent tends to allow a higher concentration of substances to be extracted. Both organic and inorganic components stored in the tissue could be withdrew using intermolecular force performed by solvent molecules. However, $\mathrm{H}_{2} \mathrm{O}$ molecule can lead to interference of substancesolvent interaction due to the presence of hydrogen bonding. Therefore, an effective drying method is an important preparation step to run a maximum rate of water evaporation. In this study, both sun and ovendrying were applied to reduce an ideal volume of water, 93\%, as reported by Holdt and Kraan (2011). These techniques were developed by adapting Masduqi et al. (2014) that demonstrated evaporation under sunlight following oven at $60^{\circ} \mathrm{C}$ as the effective method of seaweed drying. As a result, the moisture content of the sample could be classified to the lower content compared to the other species Sargassum.

Ash content can be used as a primary manner to determine the purity degree of a sample. Ash could be considered as the remaining inorganic materials from a process of sample combustion. The ash content of Lange brown algae is likely to be categorised as lower level compared to the other species and common level range for Sargassum as documented, i.e. 14-44\% (Holdt and Kraan, 2011). However, its value was fairly similar to the $S$. oligocystum (Manteu et al., 2018). Generally, geographical characteristics of the habitat of the organism and the climate and season, which are varied strongly affect the diverse reports of the content.

Table 1 Proximate composition (\%) of S. polycystum C.A. Agardh. in dried weight compared to references

\begin{tabular}{|c|c|c|c|c|c|}
\hline \multirow[b]{2}{*}{ Parameter } & \multicolumn{2}{|c|}{ S. polycystum } & \multirow{2}{*}{$\begin{array}{c}\text { Sargassum } \mathrm{sp}^{2} \\
\text { Lhok Bubon, Aceh } \\
\text { Barat }\end{array}$} & \multirow{2}{*}{$\frac{\text { S. oligocystum }{ }^{3}}{\text { Kenya coast }}$} & \multirow{2}{*}{$\frac{\text { S. vulgare }}{\text { India }}$} \\
\hline & Lange & $\begin{array}{l}\text { Pohuwato } \\
\text { Gorontalo }^{1}\end{array}$ & & & \\
\hline Moisture & 7.16 & 17.69 & 10.54 & 6.49 & - \\
\hline Ash & 13.057 & 24.51 & 52.74 & 13.08 & 19.4 \\
\hline Protein & 6.12 & 3.65 & 2.53 & 5.64 & 13.6 \\
\hline Carbohydrate & 51.77 & 53.66 & 23.77 & 71.42 & 61.6 \\
\hline Lipid & 1.57 & 0.55 & 0.79 & 0.46 & 0.5 \\
\hline Fibre & 20.33 & 6.52 & - & 9.4 & - \\
\hline
\end{tabular}

Sources: ${ }^{1}$ Manteu et al. (2018), ${ }^{2}$ Gazali et al. (2018), ${ }^{3}$ Muraguri et al. (2016), and ${ }^{4}$ Kumar et al. (2008) 
With the salinity reported as $3.15-3.25 \%$ in July (Marghany, 2014), the habitat along Lange beach could be considered as the quite less saline water compared to normal seawater with salinity as $3.5 \%$.

The protein content of the marine plant showed a relatively higher level than the species from the literature. Since the protein levels of Sargassum are between 0.3 and $5.9 \%$ (Erniati et al., 2016), the sample in this study might be reported as higher protein algae due to its content of $6.12 \%$. Therefore, this finding appears to empirically justify $S$. polycystum from Lange as a potential source of protein from which the nitrogen species could come up through the decomposition process. Theoretically, the protein in Sargassum predominantly consists of glutamic acid and aspartic acid as much as 39-41\% of its wet weight (Holdt and Kraan, 2011). However, further analysis is needed to confirm the composition of the amino acids making the algae up.

The carbohydrate content of S. polycystum reflects the standard range of Sargassum reported by Holdt and Kraan (2011), around 54.3-73.8 \%, but is considered to be low in Erniati et al. (2016), and extremely high in Venugopal (2011) as their standard ranges are $4-68 \%$ and $15-20 \%$, respectively. This species is likely to be the richness of biomass needed for other applications such as raw material for alginate, fucoidan, and laminarin. Such number also indicates that the algae could potentially be nourishing plants and soil because, generally, Sargassum polysaccharides contain abundantly sulfurous groups.

S. polycystum of Lange beach contain relatively higher lipid level compared to the literature where the value was doubled higher than those. On the other hand, this species has a slightly lower lipid level than S. crassifolium growing in Gorontalo with a fat content of $1.63 \%$ (Handayani et al., 2004). When compared to the Venugopal (2011) report on Sargassum in colder subtropical regions, Lange's species is $0.43 \%$ lower than the minimum range of the documented levels (2-4\%). This content is in agreement with Kumar et al. (2008) arguing that the tropical Sargassum fat content is $<1 \%$ lower than in colder temperatures.

The brown seaweed from the studied site was found rich in dietary fibre formed by soluble and insoluble fibre. This highlights the value of the species as a prospective source of bioactive polysaccharides and biofertilizer. The macroalgae could moisturise and maintain soil fertility through promoting aeration rate and enriching soil structure. In addition, cellulose, mannan, and xylan are likely to be extracted in sufficient quantities used as active ingredients for plant growth. The level of Sargassum fibre from Lange was almost three times higher than the species of Poluwatu. However, when compared to the data from Holdt and Kraan (2011), the levels were underneath the reported range of $33-62 \%$ yet.

\section{Analysis of $\mathrm{pH}, \mathrm{EC}$, and TDS}

The liquid product of ATS can be characterised using electrolyte parameters including $\mathrm{pH}$, TDS and EC. Based on the measurements, the $\mathrm{pH}$ of liquids 1 , $2,4,6,8$, and 10 were $6.90,6.73,6.29,4.69,7.27$, and 5.22, respectively. The fluctuated $\mathrm{pH}$ range might be associated with the organic $C$ levels representing the extracted saccharides. Higher $\mathrm{C}$ concentrations could lead to more acidic $\mathrm{pH}$ because the level allows the sample to be easily oxidised (Phibunwatthanawong and Riddech, 2019). This liquid product might be classified as the good product due to relatively high content of electrolytes ions indicated from $\mathrm{pH}$ range of 4-8 (Regulation of Ministry of Agriculture Republic of Indonesia (RMARI) number 70/SR./140/10/2011, and Seswati et al., 2013). According to Sutiyoso (2003), extracts possessing higher ion content tend to modulate plant growth.

As presented in Figure 1, the highest EC value goes to filtrate 2 afforded by heating for $2 \mathrm{~h}$. With a value of $0.078 \mathrm{dS} . \mathrm{m}^{-1}$, the filtrate should be safe for all types of plants including agricultural commodities that are sensitive to a saline environment. This liquid could be applied for hydroponic plants. Generally, the EC and TDS patterns in Figure 2 are completely alike. Those show that the number of dissolved solids in this study contributed to the value of electrical conductivity positively. On the other words, the dissolved particles observed were charged minerals consisting of cations and anions. Grace (2016) stated that TDS value is closely interrelated to EC. These findings are essential to suggest the presence of minerals commonly constituted the genus. Regarding the estimation of EC and TDS, this extract might be able to prevent yellowing leaf and stunted plants due to lower value $(\approx 0)$ and higher of the EC $\left(>5 \mathrm{dS} \cdot \mathrm{m}^{-1}\right)$ (Grace, 2016).

\section{Analysis of essential nutrients}

Macronutrient analysis results illustrated in Figure 3 represent necessary nutrient components needed to support their plants' growth. Compared to RMARI number 70, the contents of this product were relatively lower. Further research is needed to increase the levels of these macroelements to meet the minimum standards. On the other hand, all macronutrient levels in this study were somewhat 
higher than those from Sutharsan et al. (2014), Basmal et al. (2017), and Barath et al. (2018).

A liquid extract of S. crassifolium with $\mathrm{N}, \mathrm{P}, \mathrm{K}$ levels of $0.04,0.0009$, and $0.15 \%$ has been confirmed to promote both the growth rate of major organs and the volume and quality of hydroponic fruit plants (Sutharsan et al., 2014). With regards to the higher levels above $0.1 \%$, the extract of this research can be categorised as a potential biofertilizer. According to the Figure 3 , heating for $2 \mathrm{~h}$ produced an extract with the highest levels of $\mathrm{N}$. A relatively shorter period of heating could prevent the denaturation of the peptide bonds which cause the lowering solubility in water. In contrast, extract 2 has little gaps toward the extracts with the highest $\mathrm{P}$ and $\mathrm{K}$ levels, specifically 0.03 and $0.01 \%$ lower. Additionally, for organic $\mathrm{C}$ level, extraction for 360 mins resulted in the highest levels. The $\mathrm{C} / \mathrm{N}$ values for liquid $1,2,4,6,8$, and 10 were $0.716,0.642,0.9,2.5,1.667$, and 1.083, respectively. These ratios are still below the criteria of Permentan no. 70, which is at least 6.

Figure 4 shows the data of essential mineral contents in the extract. Briefly, the mineral content of $\mathrm{Na}, \mathrm{Mg}, \mathrm{Ca}, \mathrm{Zn}$, and $\mathrm{Mn}$ were under the range of the RMARI number 70, which are 250-5000 ppm. When compared to similar species from the Gorontalo Pohuwato coast (Manteu et al., 2018), S. ilicifolium ingredients in brown seaweed indicated by the

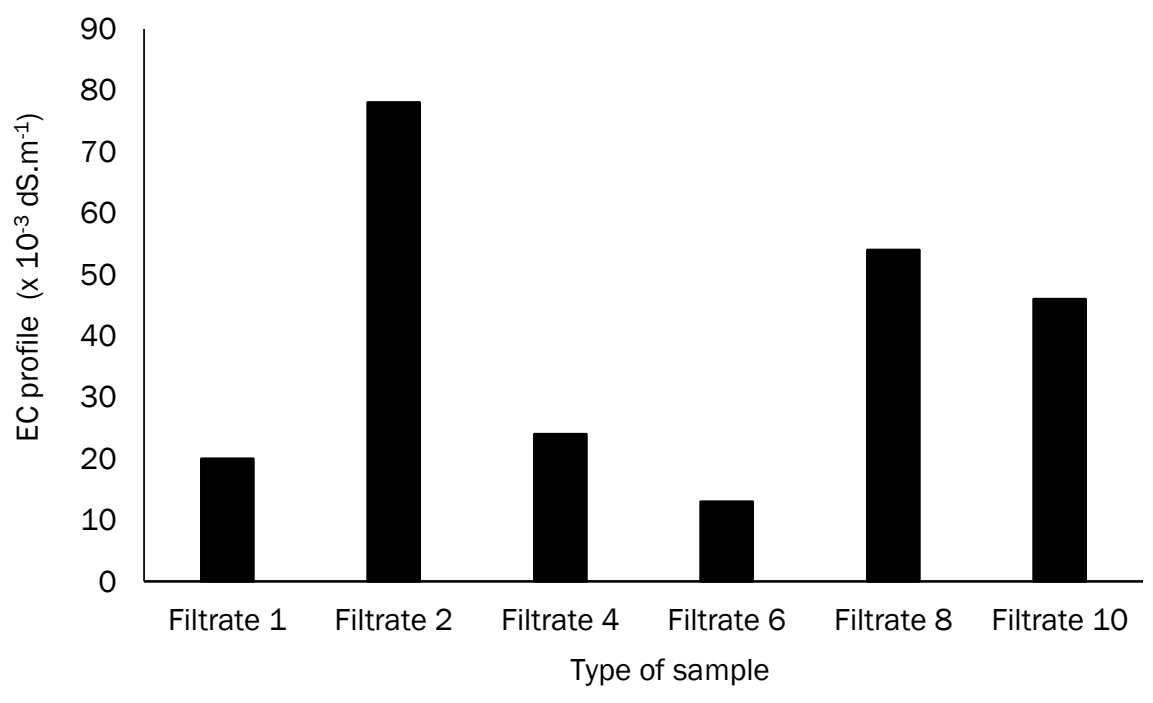

Figure $1 \mathrm{EC}$ profile of six liquid products extracted from S. polycystum from Lange beach

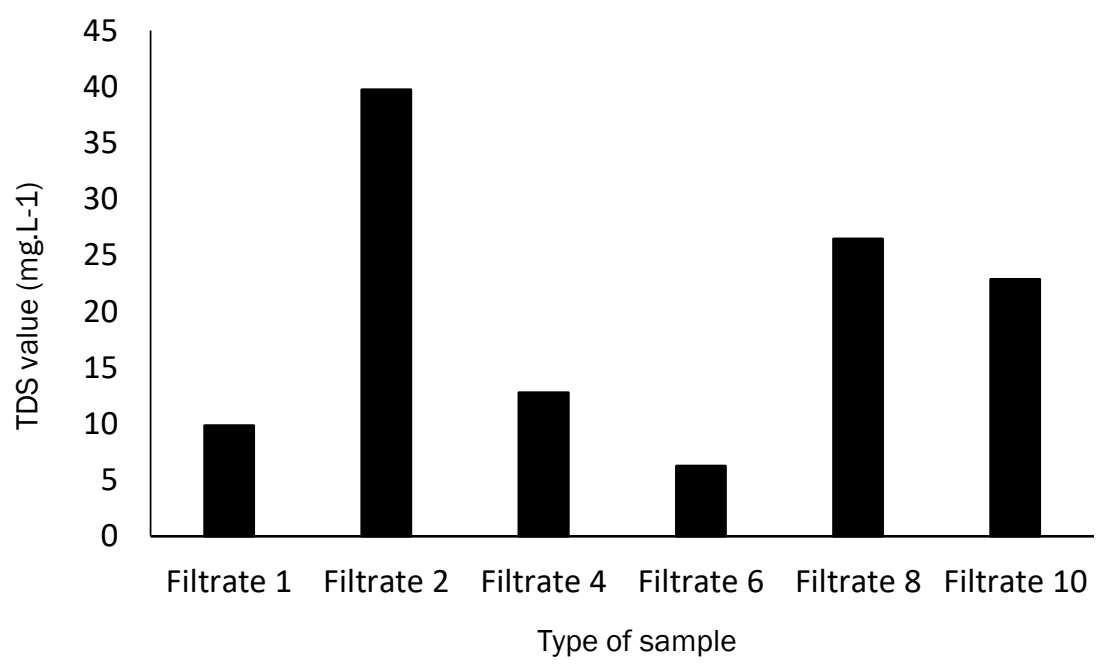

Figure 2 TDS profile of six liquid products extracted from S. polycystum from Lange beach 


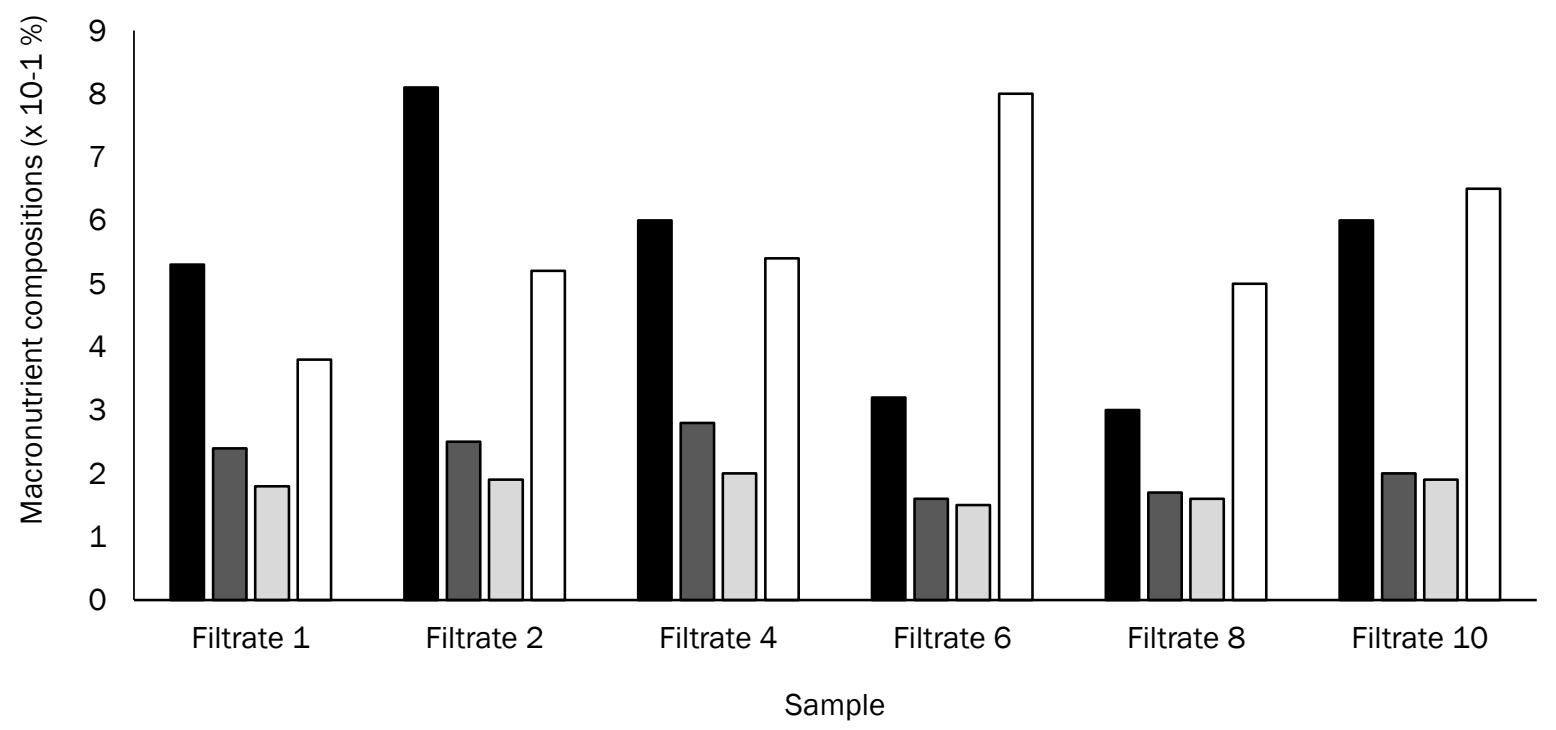

$\square \mathrm{N} \square \mathrm{P} \square \mathrm{K} \square \mathrm{Corganic}$

Figure 3 Macronutrient compositions of six liquid products extracted from S. polycystum from Lange beach

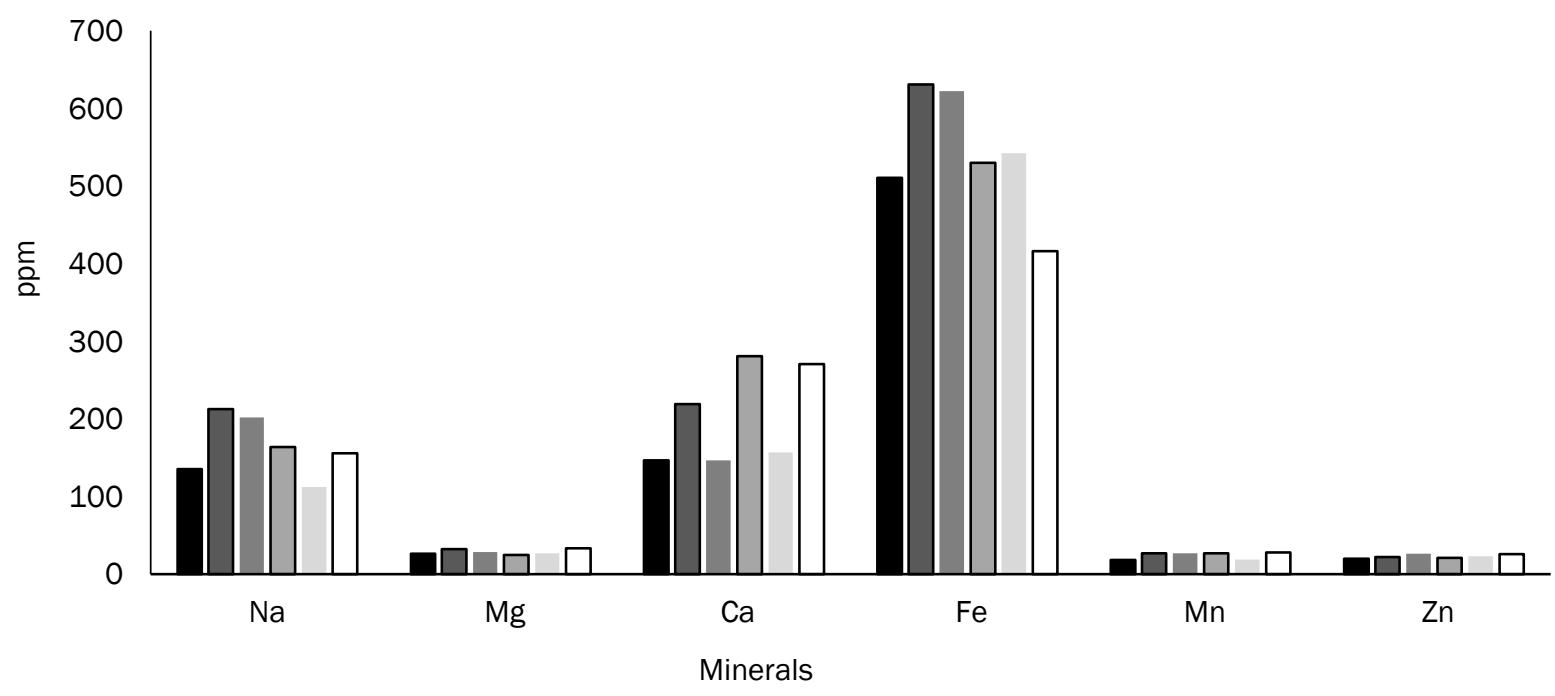

口Filtrate $1 \quad$ 口Filtrate $2 \quad$ Filtrate $4 \quad \square$ Filtrate $6 \quad$ Filtrate 8 aFiltrate 10

Figure 4 Micronutrient compositions of six liquid products extracted from S. polycystum from Lange beach

Arabian sea (Pise and Sabale, 2010b), and S. crassifolium Sri Pasikudah Beach (Sutharsan et al., 2014), the levels were higher because the sampling carried out at the peak of the dry season might affect to the quantification. Tropical S. polycystum is well recognised to be more productive in the summer with cooler temperatures (Noiraksar et al., 2017). Further research investigating the influence of location factors and sampling season is needed to clarify the hypothesis. Based on the Fe contents, all liquids possess values above the RMARI number 70 range of 90-900 ppm. Mostly, the mineral content data show that extraction for $2 \mathrm{~h}$ produced the highest concentrations except $\mathrm{Ca}$ and $\mathrm{Zn}$.

This research found that heating for $2 \mathrm{~h}$ was the optimal time in the extraction of $S$. polycystum with $0.1 \% \mathrm{KOH}$ at $80^{\circ} \mathrm{C}$. This agrees with the report recording such period as the ideal time of commercial alginate manufacture (McHugh, 2003). A well-qualified SLF is reported to have $\mathrm{pH}$ and $\mathrm{EC}$ value no more than 7 and $20 \mathrm{dS} . \mathrm{m}^{-1}$, respectively (Phibunwatthanawong and Riddech, 2019). The heat treatment during that time effectively extracts vital 
relatively higher levels of macro- and micronutrients. The longer heating time could probably dissolve more organic macromolecules into the extracts indicated by the amount of organic $\mathrm{C}$ levels in Figure 3 that can lead to reducing the concentration of essential substances. Consequently, the macromolecules as the nonpolar species may lower the electrical conductivity because they could disrupt ion-ion interactions in the system.

Compared to Basmal et al. (2017), the results of this study are extremely different. In terms of heating time, the authors confirmed that the longest heating time, $6 \mathrm{~h}$, produced the best product. Based on their EC value, the liquid may not be safe for salttolerant plants, especially for hydroponic species. Finally, the ecosystems and harvesting time can mainly drive the diversity of the characteristics of algae (Holdt and Kraan, 2011). These factors can be taken into account to dominantly playing in the significant difference between this study and the reference.

\section{Conclusion}

Based on the measured properties, $S$. polycystum C.A. Agardh from Lange beach has been fairly confirmed as a promising raw material for organic liquid fertilizer. The content of its proximate were in line with the typical requirements for SLF production. The most favourable time for necesary extraction at $80^{\circ} \mathrm{C}$ was 120 mins by which the filtrate exhibit accepted value of $\mathrm{pH}$, EC and TDS as Sargassum-based biofertilizer. Moreover, the nutrients levels were above the minimum value in each parameter as well. However, more investigations, including quantitative analysis of growing regulatory hormone as well as the application of the extract toward hydroponic crops, are needed to establish comprehensive information of the macroalgae.

\section{Acknowledgement}

The authors would like to express their gratitude to the Center for Research and Publishing (Puslitpen LP2M) of UIN Ar-Raniry for assisting in organising the timeline of the research. The funding support from DIPA UIN Ar-Raniry Banda Aceh 2019 through contract number: 429 / PPK-UIN / V / 2019 is highly appreciated as well.

\section{References}

Anisimov, M.M., \& Chaikina, E.L. 2014. Effect of seaweed extracts on the growth of seedling roots of soybean (Glycine max (L.) Merr.) seasonal changes in the activity. Int. J. Curr. Res. Aca. Rev. 2(3): 19-23.

Association of Analytical Chemist (AOAC). 2005. Official methods of analysis of the association of official analytical chemist. The Association of Official Analytical Chemist Publisher. Virginia.

Astruli. 2014. Roadmap industri rumput laut Indonesia. Bahan Presentasi Asosiasi Industri Rumput Laut Indonesia (ASTRULI) tanggal 25 November 2014.

Balai Penelitian Tanah (BPT). 2005. Analisis kimia tanah, tanaman, air, dan pupuk. Badan Penelitian dan Pengembangan Pertanian, Departemen Pertanian. Bogor.

Basmal, J. 2010. Teknologi pembuatan pupuk organik cair kombinasi hidrolisat rumput laut Sargassum sp. dan limbah ikan. Squalen, 5(2): 59-66.

Basmal, J., Chori, V.A., \& Nurhayati. 2017. Pemanfaatan limbah cair produksi alkali treated sargassum sebagai bahan baku pupuk cair. J. Pascapanen dan Bioteknologi Kelautan dan Perikanan, 12(2):135-148. doi: 10.15578/ jpbkp.v12i2.259

Basmal, J., Kusumawati, R., \& Utomo, B.S.B. 2015. Mutu sap liquid rumput laut sargassum yang diekstrak menggunakan kalium hidroksida sebagai bahan pupuk. J. Pascapanen dan Bioteknologi Kelautan dan Perikanan, 10(2):143-153 doi:10.15578/jpbkp.v10i2.365

Bharath, B., Nirmalraj, S., Mahendrakumar, M., \& Perinbam, K. 2018. Biofertilizing efficiency of Sargassum polycystum extract on growth and biochemical composition of Vigna radiata and Vigna mungo. Asian Pacific J. Reproduc., 7(1): 27-32. doi: 10.4103/230 5-0500.220982.

Darmawan, M., Tazwir, \& Hak, N. 2006. Pengaruh perendaman rumput laut coklat segar dalam berbagai larutan terhadap mutu natrium alginat. Bul. Teknol. Hasil Perikan., 9(1):26-38 doi: 10.17844/jphpi.v9i1.1001

Divya, K., \& Reddi, B.N. 2017. Influence of seaweed liquid fertilizer of Sargassum wightii, Turbnearia arnata on the seed germination, growth and productivity of vegetable crops. J. Algal Biomass Util. 8(2): 37-43.

Divya, K., Roja, N.M., \& Padal, S.B. 2015. Effect of seaweed liquid fertilizer of Sargassum wightii on germination, growth and productivity of brinjal. 
Int. J. Adv. Res. Sci. Eng. Technol., 2(10): 868871.

El-Din, S.M.M. 2015. Utilization of seaweed extracts as bio-fertilizers to stimulate the growth of wheat seedlings. Egypt. J. Exp. Biol. (Bot.), 11(1):3139.

Erniati, Zakaria, F.R., Prangdimurti, E., \& Adawiyah, D.R. 2016. Seaweed potential: bioctive compounds studies and its utilization as a functional food product. Aquat. Sci. J., 3(1):1217.

FAO. 2018a. The global status of seaeed production, trade, and utilization. Globefish Research Programme Volume 124. Rome. $120 \mathrm{pp}$. Licence: CC BY-NC-SA 3.0 IGO.

FAO. 2018b. The state of world fisheries and aquaculture 2018-Meeting the sustainable development goals. Rome. Licence: CC BY-NCSA 3.0 IGO.

Gazali, M., Nurjanah, \& Zamani, N.P. 2018. Eksplorasi senyawa bioaktif alga cokelat Sargassum sp. Agardh sebagai antioksidan dari pesisir barat Aceh. J. Pengolah. Has. Perikan. Indo. 21(1): 167-178. doi: 10.17844/jphpi.v2 $1 \mathrm{i} 1.21543$.

Grace. 2016. Understanding water quality, water EC, and $\mathrm{pH}$. Aessense Applications Scientist.

Handayani, T., Sutarno, T., \& Setyawan, A.D. 2004. Analisis komposisi nutrisi rumput laut Sargassum crassifolium. J. Agardh. Biofarmasi 2: $45-52$

Holdt, S.L., \& Kraan, S. 2011. Bioactive compounds in seaweed: functional food applications and legislation. J. Appl. Phycol., 23(3): 543-597. doi: $10.1007 / \mathrm{s} 10$ 811-0 =10-9632-5.

Kementerian Kelautan dan Perikanan (KKP). 2013. Buku saku: informasi rumput laut. Direktorat Usaha dan Investasi Direktorat Jenderal Pengolahan dan Pemasaran Hasil Perikanan. Jakarta.

Kumar, C.S., Ganesan, P., Suresh, P.V., \& Bhaskar, N. 2008. Seaweeds as a source of nutritionally beneficial compounds-a review. J. Food Sci. Technol., 45: 1-13.

Manteu, S.H., Nurjanah, \& Nurhayati, T. 2018. Karakteristik rumput laut cokelat (Sargassum policystum dan Padina minor) dari perairan
Pohuwato Provinsi Gorontalo. J. Pengolah. Hasil Perikan. Indo., 21(3): 396-405.

Marghany, M. 2014. Simulation of tsunami impact on sea surface salinity along Banda Aceh coastal waters, Indonesia. In: Advanced Geoscience Remote Sensing (Ed), p: 229-251. doi: 10.57 $72 / 58570$.

Masduqi, A.F., Izzati, M., \& Prihastanti, E. 2014. Efek metode pengeringan terhadap kandungan bahan kimia dalam rumput laut Sargassum polycystum. Bul. Anatomi Fisiologi, 22(1): 1-9. doi: 10.14710/baf.v22i1.7804.

McHugh, D.J. 2003. A guide to the seaweed industry. Food and Agriculture Organization of The United Nations. Rome.

Muraguri, E.N., Wakibia, J.G., \& Kinyuru, J.N. 2016. Chemical composition and functional properties of selected seaweeds from the Kenya coast. J. Food Res., 5(6): 114-123. doi: 10.5539/jfr.v5 n6p114.

Muslimin \& Sari, W.K.P. 2017. Budidaya rumput laut Sargassum sp. dengan metode kantong pada beberapa tingkat kedalaman di dua wilayah perairan berbeda. J. Riset Akuakultur 12(3): 221-230. doi: 10.15578/jra.12.3.2017.221-2 30.

Nayar, S. \& Bott, K. 2014. Current status of global cultivated seaweed production and markets. World Aquaculture: 32-37.

Noiraksar, T., Manthachitra, V., Buranapratheprat, A., \& Komatsu, T. 2017. Growth and reproductive seasonal pattern of Sargassum polycystum C. Agardh (Sargassaceae, Phaeophyceae) population in Samaesarn Island, Chon Buri Province, Thailand. La mer, 55: 11-23.

Patel, J.V., Brahmbhatt, N., Patel, H.D., Patel, R.V., \& Thaker, P. 2019. Effect of brown seaweed extract of Sargassum Johnstonii on vegetable plant growth and biochemical constituent. Int. J. Adv. Res. Sci. Eng. Technol., 7(3): 2113-2119. doi: 10.22214/ijraset.2019.3391.

Phibunwatthanawong, T., \& Riddech, N. 2019. Liquid organic fertilizer production for growing vegetables under hydroponic condition. Int. J. Recycl. Organic Waste Agricul., 8(4): 369-380. doi: $10.1007 /$ s40093-019-0257-7.

Pise, N.M. \& Sabale, A.B. 2010a. Effect of seaweed concentrates on the growth and biochemical 
constituents of Trigonella foenum-graecum L. J. Phytolog., 2(4): 50-56.

Pise, N.M., \& Sabale, A.B. 2010b. Biochemical composition of seaweeds along central west coast of India. J. Phytolog., 2(7): 148-150. doi: 10.1016/S0975-3575(10)80082-3.

Pusat Data, Statistik dan Informasi (Pusdatin). 2018. Kelautan dan perikanan dalam angka tahun 2018. Kementerian Perikanan dan Kelautan (KKP). Jakarta.

Regulation of Ministry of Agriculture Republic of Indonesia. Peraturan Menteri Pertanian nomor 70/Permentan /SR.140/ 10/2011 tentang pupuk organik, pupuk hayati dan pembenah tanah.

Salim, Z., \& Ernawati. 2015. Info Komoditi Rumput Laut. Badan Pengkajian dan Pengembangan Kebijakan Perdagangan, Kementerian Perdagangan Republik Indonesia. Jakarta.

Salma, L., Aymen, E.M., Maher, S., Hassen, A., Chérif, H., Halima, C., Mounir, M., \& Mimoun, E. 2014. Effect of seaweed extract of Sargassum vulgare on germination behavior of two bean cultivars (Phaseolus vulgaris L) under salt stress. J. Agric. Vet. Sci., 7(2): 116-120. doi: 10.9790/23800721116120.

Seswati, R., Nurmiati, \& Priadnadi. 2013. Pengaruh pengaturan keasaman media serbuk gergaji terhadap pertumbuhan dan produksi jamur tiram cokelat (Pleurotus cystidiosus O.K. Miller.). J. Biologi Universitas Andalas., 2(1): 31-36. doi: 10.25077/jbioua.2.1.25p.2013.
SNI 4146:2013. 2013. Cara uji kadar nitrogen total sedimen dengan distilasi Kjeldahl secara titrimetri. Badan Standarisasi Nasional. Jakarta.

Spurr, H.I. 2014. Extraction, separation and purification of polyphenols, polysaccharides and pigments from British seaweed for high-value applications. Dissertation. The University of Leeds. Leeds.

Sujatha, K., Vijayalakshmai V., \& Suganthi, A. 2015. Comparative efficacy of brown, red and green seaweed extracts on low vigour sunflower (Helianthus annus L.) var. TN (SUF) 7 seeds. Afr. J. Agric. Res. 10(20): 2165-2169. doi: 10.5897/AJAR2013.7942.

Sutharsan, S., Nishanthi, S., \& Srikrishnah, S. 2014. Effects of foliar application of seaweed (Sargassum crassifolium) liquid extract on the performance of Lycopersicon esculentum Mill. in sandy regosol of Batticaloa District Sri Lanka. American-Eurasian J. Agric. \& Environ. Sci., 14 (12):1386-1396. doi: 10.5829/idosi.aejaes. 2014.14.12.1828.

Sutiyoso. 2003. Meramu pupuk hidroponik. Penebar Swadaya. Jakarta. 122 pp.

Takoliya, H.H., Brahmbhatt, N., Patel, R.V., \& Takoliya, H.H. 2019. Improving soil fertility and seed germination using seaweed liquid fertilizer of Sargassum wightii and Sargassum johnstonii. Int. J. Green and Herbal Chem. 8(1): 161-179. doi: 10.24214/IJGHC/GC/8/1/16 179.

Venugopal, V. 2011. Marine polysaccharides: food applications. CRC Press Taylor \& Francis Group. New York. 396 pp. 